\title{
Comparaçōes morfológicas e histoquímicas da bexiga natatória de peixes teleósteos de respiração aquática e respiração aérea (*)
}

\author{
Maria Alice da Cruz-Höfling (') \\ Carminda da Cruz-Landim ( ${ }^{2}$ ] \\ Alba Sanches Patelli (')
}

\begin{abstract}
Resumo
As bexigas natatórias do Hoplerythrinus unitaenitus (jeju), eritrinídeo de respiração aérea facultativa e do Osteoglossum bicirrhosum (aruanā), osteoglossídeo de respiração aquática, foram comparadas morfológica e histoquimicamente. No jeju, a bexiga tem funçāo respiratória, enquanto no aruanã é um órgão hidrostático. Ambos são fisóstomos e a bexiga natatória é dividida em duas câmaras, cujas paredes são constituídas por três túnicas. Existem características morfológicas próprias de cada espécie, particularmente em relação à túnica interna: no jeju forma pregas aumentando assim a sua superfície; apresenta rico plexo capilar sub-epitelial e coxins musculares laterais. Os testes histoquímicos mostram que a bexiga natatória do jeju, contém mucopolissacárides, substâncias redutoras, lipides, colesterol e compostos afins: calciferol, ions férricos e proteínas. Há também fibras elásticas as quais estão em maior quantidade na porção anterior da câmara posterior. Com exceção das fibras elásticas, esses componentes localizam-se preferencialmente, no epitélio, lâmina própria e junto aos vasos sangüíneos, principalmente próximo aos coxins musculares. No aruanā, cs testes para estas substâncias foram negativos, exceto alguns que se mostraram discretamente positivos no epitélio e a presença de fibras elásticas. Supõe-se que estes compostos químicos presentes no jeju tenham importância funcional na respiração desempenhada pela bexiga natatória.
\end{abstract}

\section{INTRODUÇÃo}

Tem sido objeto de grande interesse o estudo dos aspectos morfológicos e funcionais apresentados por diversas estruturas em peixes teleósteos, que desenvolveram adaptações para a transição da respiração aquática para a respiração aérea (Lüling, 1964; Junqueira et al., 1967; Johansen et al., 1967; Johansen. 1970), dentre as quais a bexiga natatória, bem como as condições ambientais que as propi. ciaram (Carter, 1957; Jones \& Marshall, 1953; Weibezahn, 1967; Graham et al., 1978; Phleger \& Saunders, 1978).

É de importância a observação comparatiVà das alterações morfológicas apresentadas pela bexiga natatória quando esta deixa de ser um órgão com função hidrostática e passa a ter adaptações para a respiração aéreà. Com este propósito, resolvemos comparar as bexigas natatórias do Osteoglossum bicirrhosum, que tem respiração aquática e portanto utiliza esse órgão para flutuação, e a do Hoplerythrinus unitaeniatus que tem respiração aérea facultativa, e utiliza a bexiga natatórı como pulmão, quando o teor de oxigênio da água é baixo. Estudos da uitraestrutura da bexiga na tatória desses peixes foram efetuados por CruzLandim \& Cruz-Höfling (1979) com o intuito de verificar aspectos morfológicos associados evolutivamente à mudança de função.

A presença de um epitélio pavimentoso de revestimento, de um vasto plexo capilar, dos citossomas na bexiga natatória do $H$. unitaeniatus (jeju), pode ser especializações com papel nas trocas gasosas, durante a respiração aerea (Cruz-Landim \& Cruz-Höfling, 1979). A sua presença confere semelhanças estruturais com as descritas em pulmões de vertebrados superiores (Brooks, 1970; Hughes \& Weibel, 1978) .

Por outro lado, Pattle (1955) descobriu uma substância surfactante que reveste os alvéolos pulmonares de mamíferos, a qual forma um filme na interface ar-líquido, que reduz a tensão superficial. A natureza química desse composto não está ainda bem determinada,

$\left({ }^{\circ}\right)$ - Pesquisa financiada pelo CNPq e NSF Grant n.० BNS75 - 10457 AO 1

(1) - Instituto de Biologia - UNICAMP - Campinas, SP.

(2) - Instituto de Biociências - UESP - Rio Claro, SP. 
mas sabe-se que é constituído por água, lípides e proteínas (Brown, 1964), e foi descrita em pulmões de peixes, anfíbios, répteis e aves (Pattle \& Hopkinson, 1963; Hughes, 1966; 1973; Pattle, 1976; Phleger \& Saunders, 1978).

O objetivo deste trabalho é o estudo histológico comparativo de bexigas natatórias, que funcionam, ou como órgão hidrostático, ou como órgão de respiração aérea, bem como detectar a presença e natureza de compostos químicos nestes órgãos, através de técnicas histoquímicas.

\section{MATERIAL E MÉTODOS}

As observações foram efetuadas em bexigas natatórias de Osteoglossum bicirrhosum - Osteoglossidae (aruanã) e de Hoplerythrinus unitaeniatus - Erythrinidae (jeju), ambos fisóstomos. O jeju foi coletado no lago Janauacá, rio Solimões, enquanto o aruanã o foi no Arquipélago das Anavilhanas, rio Negro (Bacia Amazônica - Brasil), a bordo do R/V AlphaHelix, em janeiro de 1977. No jeju, foram feitas observações na porção anterior e posterior da bexiga natatória, porque anatomicamente, essas porçōes se apresentavam respectivamente, pouco e muito vascularizadas. Para os exames histológicos as bexigas natatórias foram fixadas em formol-cálcio (solução de formalina a $15 \%$, contendo $3 \%$ de cloreto de cálcio anidro). As secções em parafina $(7 \mu \mathrm{m})$ foram submetidas a colorações histológicas de rotina: Hematoxilina-Eosina, Tricrômico de Gomori e Tricrômico de Masson, e a coloração de Gomori para fibras elásticas (Gomori, 1950). Para propósitos histoquímicos. foram utilizados, tanto cortes de tecido em parafina, $(7 \mu \mathrm{m})$, como em congelação $(12 \mu \mathrm{m})$ e efetuados os seguintes testes: 1) reação do P.A.S. (Mc Manus, 1946, modificado por Hotchkiss, 1948) para demonstração de grupos vicglicólicos. A verificação da presença de glicogênio foi feita pelo tratamento prévio com amilase salivar por 45 minutos, e a extração dos lípides PAS positivos se fez por solução de desoxicolato de sódio a $2 \%$ ( 8 horas a $47^{\circ} \mathrm{C}$ ), antes da reação do PAS; 2) reação do ferricianeto férrico (Adams, 1956) para evidenciação de grupos redutores; o bloqueio $d \epsilon$ grupos sulfidrilos (-SH) foi feito pelo trata- mento prévio pelo bicloreto de mercúrio por 6 horas a $\left.37^{\circ} \mathrm{C} ; 3\right)$ coloração pelo Negro de Sudan B (Lison, 1960) para detecção de lípides totais; 4) reação do permanganato de potássio em meio ácido-azul de toluidina $0,5 \%, \mathrm{pH} 0,5$ para demonstração de colesterol e compostos afins (Hadler et al., 1968); 5) reaçâo do per. manganato de potássio em meio básico-azul de toluidina $0,5 \%, \mathrm{pH} \quad 0,5$ para detecção de calciferol (Hadler \& Silveira, 1977); 6) reação de ácido perfórmico-azul de toluidina 0,5\%, pH 0,5 para tocoferol (Hadler \& Silveira, 1977); 7) reação da ninhidrina-Schiff (Yasuma \& Itchikawa, 1953) para grupos $\mathrm{NH}_{2}$ ligados às proteinas; 8) reação do Azul da Prússia, modificada por Hadler et al. (1969) para íons férrico.

\section{Resultados}

A estrutura da bexiga natatória difere em alguns pontos nas duas espécies de peixes estudadas. Há também algumas diferenças regionais na constituição histológica da porção anterior e posterior da bexiga natatória do jeju.

\section{RESULTADOS HISTOLÓGICOS}

\section{Hoplerythrinus unitaeniatus (jeju)}

A bexiga natatória do $H$. unitaeniatus consta de uma câmara anterior e uma câmara posterior mais longa e cônica, divididas por um esfíncter ou ducto comunicante. A porção anterior da câmara posterior é muito vascularizada. Um ducto-pneumático liga a porção ântero-ventral da câmara posterior ao esôfago.

A parede da bexiga natatória é basicamen. te constituida por três túnicas (fig. 1); a túnica interna é formada por tecido epitelial que limita a luz e uma lâmina própria deigada de tecido conjuntivo frouxo junto ao epitélio e mais denso, próximo da túnica média. Nesse tecido conjuntivo frouxo, o número de capila. res sangüíneos é muito grande. A túnica média é constituída por duas camadas de fibras musculares lisas, bem definidas, uma longitudinal interna delgada e outra circular, externa espessa. Feixes de fibras musculares longitudinais esparsos podem ser vistos externamen- 


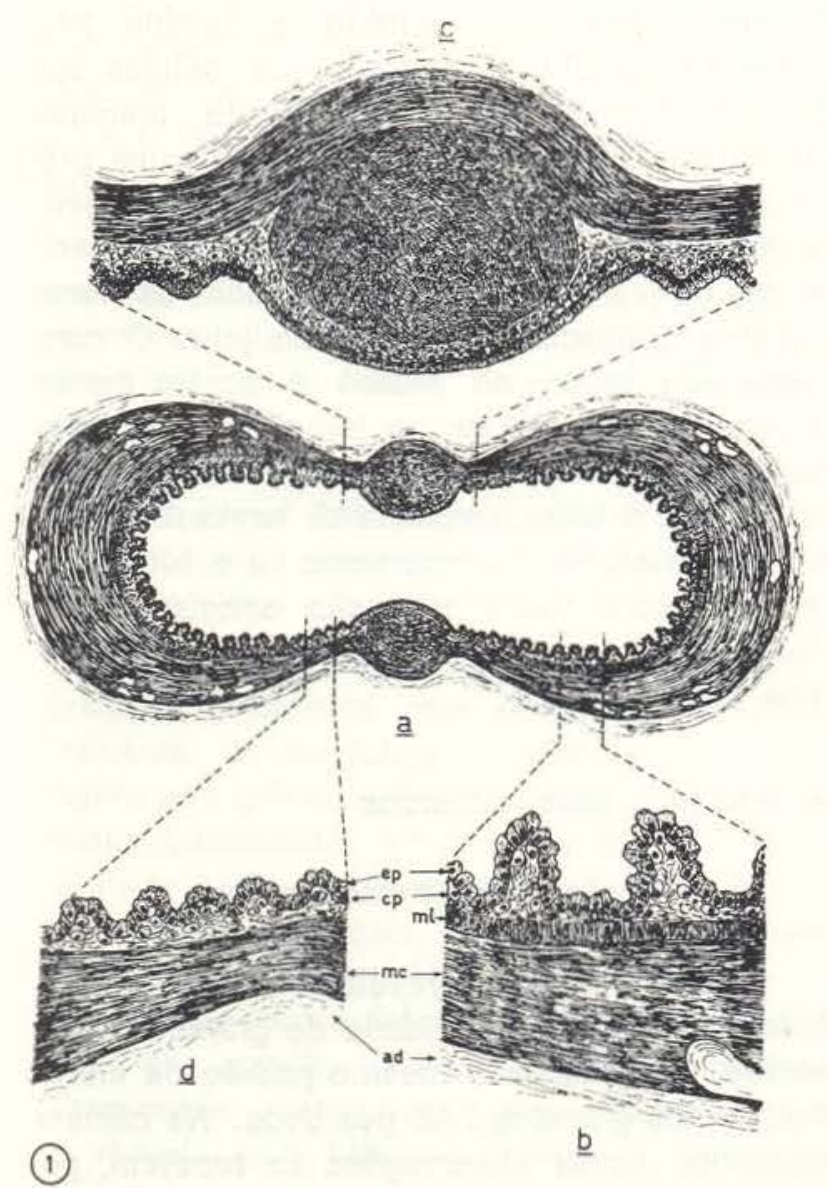

Fig. 1 - a: Esquema de corte transversal aa bexiga natatória do H. unitaeniatus; b: Detalhe mostrando as túnicas interna (ti) média ( $\mathrm{tm}$ ) e externa (te); c: DetaIhe da região do coxim: d: Detalhe da região adjacente zo coxim; ep - epitélio; $\mathrm{cp}$ - rede capilar; $\mathrm{ml}$ - muscular longitudinal; mc - muscular circular: ad - adventícia.

te à camada circular. A túnica externa é cons tituída por uma camada adventícia de conjuntivo com vasos sangüíneos de grande calibre. Uma banda lateral ou coxim de fibras musculares lisas correm em sentido iongitudinal per todo o comprimento da bexiga, a qual em secção transversal, faz uma saliência arredondada para o lúmen. Nessa região, há algumas alte. rações na constituição histológica da bexiga .

O epitélio é simples com células de forma muito variável: achatadas, cuboidais ou colunares (fig. 2). As células achatadas (fıg. 3) se encontram principalmente na câmara pơs. terior, enquanto as colunares predominam na. anterior. O epitélio forma evaginações acompanhadas pelo tecido conjuntivo, constituindo assim papilas que se projetam para o lúmen. com exceção da região dos coxins onde sua superfície é lisa (fig. $1 a, b$ e $c$ ). As células epiteliais apresentam núcieo basal, citoplasma basófilo e superfície apical arredondada (fig. 2) Fazendo interface entre a porção epitelial e a conjuntiva, há vasto leito capilar (fig. 2, 3) muito desenvolvido na porção cefálica da câmara posterior e menos deserivolvicio na porçăo caudal da mesma, bem como na câmara anterior. Nas regiōes laterais aos coxins, como se vê na fig. 1a e fig. 4, a parede da bexiga natatória é menos espessa; ai o número de capilares sub-epiteliais é muito grande, as células epiteliais apresentam grânulos citoplasmáticos refringentes, e o tecido conjuntivo frouxo é abundante (fig. 3). A coloração seletiva para fibras elásticas, através da aldeido. fucsina revela que na câmara anterior as fibras elásticas estão na lâmina própria, na muscular externa e na adventícia. Elas tornam-se mais aglomeradas nos limites de cada camada formando uma limitante interna e outra externa (fig. 7). Na camada muscular, formam um tipo de tecido muscular elástico.

A túnica muscular é constituída por uma camada longitudinal interna e uma camada circular externa (fig. $1 b$ e 2). Podem aparecer feixes de fibras musculares longitudinais esparsos entre esta e a túnica externa, sem contudo, constituir uma camada individualizada. Nos coxins e nas proximidades laterais, a pa. rede da bexiga natatória é fina e apresenta somente a circular (fig. $1 c$ e $1 d$ ). A camada circular é cerca de 5 a 8 vezes mais espessa do que a camada longitudinal, exceto no local dos coxins, onde ela é muito delgada. Há vasos sangüíneos grandes e pequenos na muscular externa, os quais estão dispostos sime. tricamente na parede do órgão. Na câmara posterior da bexiga, não é tão evidente a presença da camada de fibras musculares longitudinais internas. A túnica externa ou adventícia (fig. 5) consiste de tecido conjuntivo pouco denso, vasos sangüíneos e contém aglomerados de grânulos grosseiros, poilimorfos, em geral situados no tecido adjacente aos va. sos sangüineos. 


\section{Osteoglossum bicirrhosum (aruanã)}

A bexiga natatória do $O$. bicirrhosum cons. ta também de duas câmaras, e está situada dorsalmente ao tubo digestivo, ligando-se ao esôfago através de um duto pneumático que parte da câmara anterior.

A parede da bexiga natatória do aruanã é menos espessa do que a do jeju. Além disso, sua parede dorsal é cerca de três vezes mais delgada do que a ventral (fig. 6). Como no jeju, a bexiga natatória apresenta três túnicas, e diferentemente, do jeju, não apresenta coxins musculares. A túnica interna

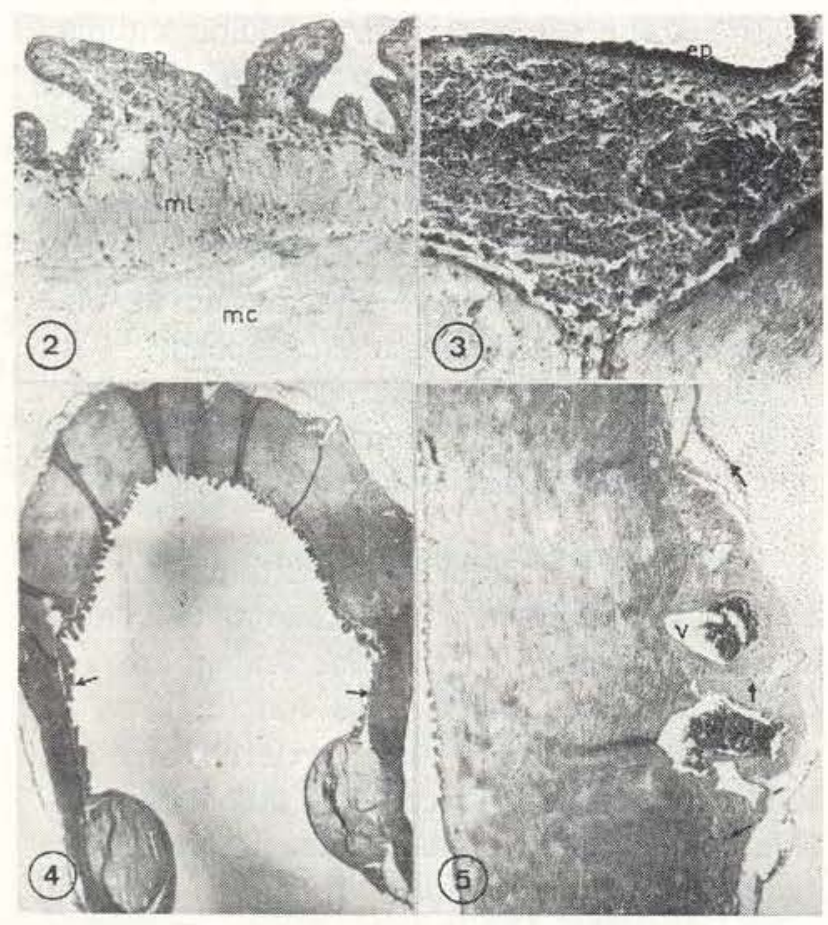

Fig. 2-5 - Corte histológico da câmara posterior da bexiga natatória: $\mathrm{H}$. unitaeniatus; notar o epitélio simples e a grande quantidade de capilares subepiteliais; ep - epitélio; I - lâmina própria, $\mathrm{ml}$ - muscular longitudinal; mc - muscular circular. HE X 340. 3 - Epitélio plano, (ep) não franjado, da região dos coxins, com grânulos refringentes; vasta rede capilar na lâmina própria (I) de tecido conjuntivo frouxo. H. unitaeniatus $\mathrm{HEX}$ X30. 4 - Aspecto histológico geral da bexiga natatória do $\mathbf{H}$. unitaeniatus em corte transversal; notar a diminuição da espessura da parede próximo aos coxins (setas), devido à ausência da muscular longıtudinal e adelgaçamento da muscular circular. Aldeído fucsina. X 85. 5 - Vasos sanguíneos (v) e grânulos grosseiros (setas) situados na adventícia da câmara posterior (H. unitaeniatus). Tricrômico de Gomori. X. 85 . é constituída pelo epitélio e lâmina própria. O epitélio é simples, de células baixas, e forma evaginações muito menores (micropapilas) do que no jeju. A lâmina própria acompanha essas evaginações, é delgada e não contém os capilares subepiteliais observados no jeju. Abaixo, estão situadas as fibras elásticas, distribuídas, como no jeju. O componente elástico no aruanã é porém menos representativo do que no jeju. A túnica muscular se dispõe em uma camada interna circular e uma externa longitudinal; nesta última há vasos e nervos. Externamente há a túnica adventícia com vasta irrigação sangüínea. $\mathrm{Na}$ face ventral da bexiga, a adventícia está revesticia por mesotélio.

\section{RISULTADOS HISTOQUÍMICOS}

\section{Hoplerythrinus unitaeniatus}

A aldeído-fucsina revela, além das fibras elásticas, grande quantidade de grânulos grosseiros, que exibem o mesmo padrão de distribuição dos grânulos PAS positivos. Na câmara posterior, essas observações se repetem, porém de maneira mais marcante. As limitantes interna e externa são mais espessas e a quantidade de grânulos grosseiros é maior, principalmente na porção delgada da parede da bexiga.

Os resultados fornecidos pela reação do PAS em cortes histológicos da bexiga natatória do jeju, permitem evidenciar na porção cefálica da câmara posterior, grupos de grânulos esféricos de vários tamanhos que são PAS positivos: são encontrados na porção apical do epitélio, sob o epitélio, abaixo da limıtante interna de fibras elásticas, por fora da túnica média muscular e na adventícia próximo aos grandes vasos. Esses grânulos PAS positivos são muito abundantes no tecido conjuntivo frouxo da lâmina própria (fig. 8), situados ao lado dos coxins e no conjuntivo adjacente a eles, onde a parede da bexiga natatória é mais delgada. Na câmara anterior os grânulos PAS positivos são menos abundantes e são observados na lâmina própria, ao lado dos coxins e na adventícia junto a vasos sangüíneos. É de notar-se que as fibras elásticas também são reativas ao PAS. Sob o epitélio, há uma linha 
fortemente corada, tortuosa, que projeta ramificações para a lâmina própria, sugerindo ser a membrana basal do epitélio e dos capilares subepiteliais, que reagem ao PAS.

Tentativas para determinar a natureza do material PAS positivo, efetuadas através do pré-tratamento com a amilase salivar e com o desoxicolato de sódio, revelaram não haver diminuição na intensidade da reação, após esses tratamentos. Estes resultados mostram que o material PAS positivo não é constituído por glicogênio, nem por lípides livres ou fracamente ligados à proteínas.

A reação do ferricianeto férrico revelou grânulos grosseiros, que se coram em verde brilhante, de morfologia e distribuição semeIhante aos grânulos PAS positivos, embora em menor quantidade. Situam-se preferencialmen te junto aos vasos sangüíneos e ao lado dos coxins; alguns locais da lâmina própria também os apresentam (fig. 9). Na câmara anterior, são menos freqüentes. As fibras elásticas e o epitélio da bexiga natatória também apresentam reatividade. Esta reatividade não é afetada pelo bloqueio com o bicloreto de mercúrio, revelando que estes grânulos contém substância redutora destituída de grupos sulfidrilas.

A coloração pelo Negro de Sudan B mostra que os grânulos PAS positivos, são também sudanófilos, pois se assemelham quanto à forma e disposição aos acima mencionados. Eles são mais abundantes na câmara posterior. Sob o epitélio que reveste os coxins, o número de grânulos Sudan positivo é muito grande (fig. 10 e 11). A sudanofilia dos grânulos revela a presença de lípides em sua composição.

A reação para demonstração do colesterol e compostos afins, revelou epitélio intensamente metacromático na câmara posterior da bexiga natatória. Há também grânulos de forma esférica corados metacromaticamente na lâmina própria e dispersos na túnica muscular (fig. 12), sendo notável a grande quantidade de grânulos metacromáticos nos coxins e adjacências. Inúmeros mastócitos são vistơs na lâmina própria e principaimente na adventíciá. As fibras elásticas aparecem ortocromáticas. Este padrão de reatividade é repetido na câma. ra anterior da bexiga natatória.
As reações para demonstração de calciferol e tocoferol mostraram que $\sigma$ epitélio apresenta maior basofilia que nos controles, sem

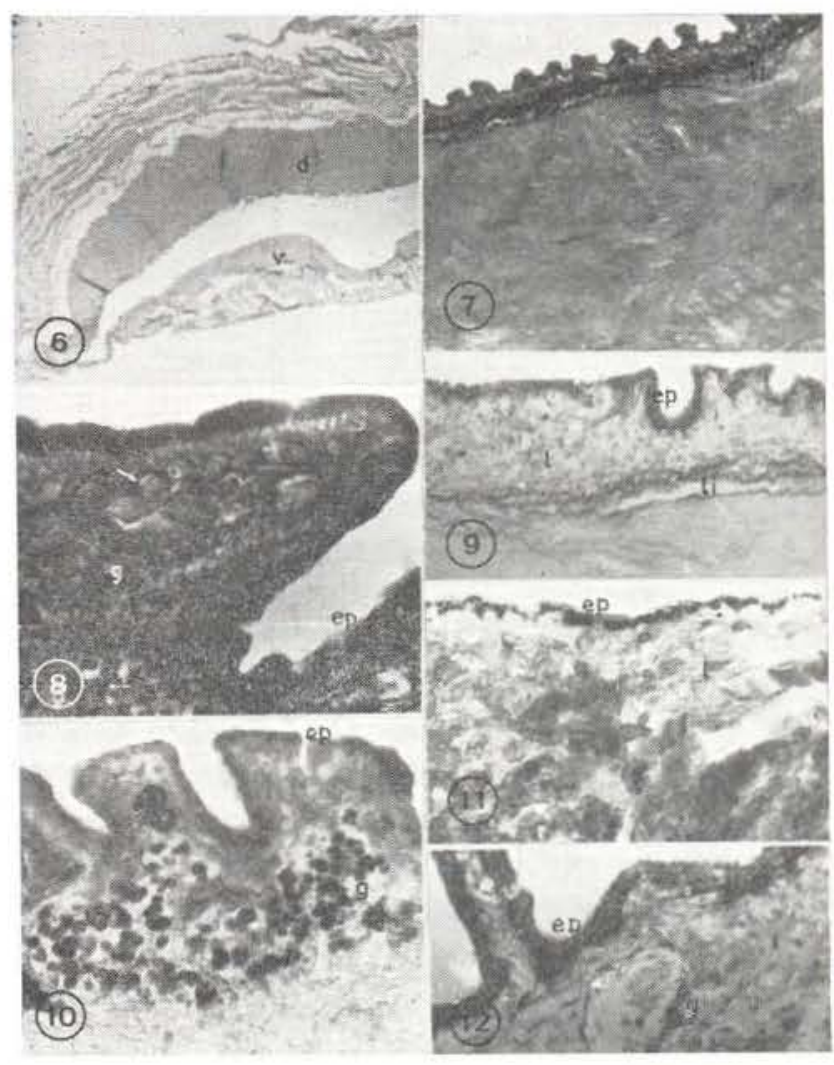

Fig. 6-12 - Bexiga natatória do 0 . bicirrhosum em secção transversal, onde se nota ausência de coxins e parede dorsal (d) mais delgada que a ventral (v). HE. X 40, 7 - Fibras elásticas formando uma limitante interna (Ii) entre a lâmina própria e a túnica muscular (H. unitaeniatus). Aldeído fucsina. X 210, 8 Grande quantidade de grânulos $(g)$ polimorfos PAS+, situados na lâmina própria adjacente aos coxıns. São também PAS positivos, porção apical do epitélio (ep) e a membrana basal do epitélio e dos capilares (setas). (H. unitaeniatus) PAS. X 540. 9 - Positividade do epitélio (ep), dos grânulos presentes na lâmina própria (1) e das fibras elásticas que constituem a limitante interna (li) à reação do ferricianeto férrico. (H. unitaeniatus). X 340, $10-$ Sudanofilia do epitélio franjado (ep) localizado distante dos coxins, devido à presença de grânulos finos. Grânulos grosseiros polimorfos (g) intensamente corados na lâmina própria. $\mathbf{~} \mathbf{H}$. unitaeniatus, negro de Sudan B. X 540, 11 - No epitélio que reveste os coxins, presença de grânulos grosseiros e intensamente sudanófilos. (H. unitaeniatus) negro de Sudan B. X 540, 12 - Intensa reação metacromática do epitélio (ep), da membrana basal (seta) e de grânulos $(\mathrm{g})$ localizados na lâmina própria $(\mathrm{H}$. unitaeniatus), reação do $\mathrm{KMnO}_{4}$ em meio ácido-azul de toluiaina $0.5 \%, \mathrm{pH} 0.5 \times 540$. 
oxidação. Por outro lado, as fibras elásticas mostram conter calciferol. Essas observações são válidas tanto para a câmara anterior, como para a posterior da bexiga natatória do jeju.

A reação do Azui da Prússia para demonstrar o íon férrico, efetuada em cortes histológicơs da câmara anterior, é tênue no epitélio, porém, próximo aos vasos sangüíneos, mostra grânulos grosseiros fortemente reativos. Na câmara posterior, aparece coloração azulada nas adjacências dos coxins, sendo mais forte na porção epitelial e no tecido conjuntivo frouxo de sua base.

A reação da ninhidrina-Schiff apresenta reatividade fraca generalizada por toda a parede da bexiga, que se intensifica nas granulações grosseiras, PAS positivas. As células epiteliais situadas ao lado dos coxins apresentam citoplasma com coloração rosa-brilhante. Nos limites entre a túnica média e a túnica externa há aglomerados destes grânulos, principalmente nas adjacências dos vasos sangüineos. Estes resultados, revelam que as reteridas granulações contém proteínas.

\section{Osteoglossum bicirrhosum}

Os resultados obtidos através das reaçōes do PAS, do ferricianeto férrico, do permanganato de potássio em meio ácido-azul de toluidina $0,5 \%$, da ninhidrina-Schiff e da coloração pelo negro de Sudan B, mostram-se negativos em toda a parede da bexiga natatória exceto no epitélio que se mostra fracamente positivo. As reações para calciferol, tocoferol e ion férrico foram negativas.

\section{DISCUSSÃo}

As observações deste estudo, juntamente com as citadas no trabalho anterior (CruzLandim \& Cruz-Höfling, 1979) mostram que as bexigas natatórias do jeju, que tem respiração aérea facultativa, apresentam caracteres morfológicos e histoquímicos, que permitem compará-las com os pulmões dos vertebrados su. periores, o que não é constatado nas bexigas natatórias do aruanã, que tem respiração aquática obrigatória. Esta similaridade parece cons tituir base para uma identidade de função. O jeju tem um número de especializações que aumentam grandemente a sua capacidade para respiraçăo aérea: epitélio de células baıxas, evaginaçōes do epitélio e microvilosidades, grande quantidade de capilares sangüineos subepiteliais e polarização da célula. Tem também aparência de tecido secretor, semelhante ao que se encontra em mamíferos, no corpo ciliar e no plexo coróide dos ventrículos. Além disso, há grande contingente de hibras elásticas, que formam verdadeiras limitantes externa e interna, as quais são mais proeminentes na câmara posterior, e dão elasticidade ao órgão. O componente elástico, como também o muscular liso estão provavelmente, engajados em processos mecânicos do órgão, nas alterações de volume, durante os processos ventilatórios e respiratórios. O jeju é um peixe que vive no fundo, em águas paradas ou correntes e vem à superfície para respirar, enquanto o aruanã vive à superfície (Menezes, comunicação pessoal). A presença maıs acentuada de estruturas relacionadas à função mecânica no jeju, parece ter relação com o maior esforço e energia despendidos por este peixe em função de seu habitat. Da mesma forma, os coxins musculares, podem ter papel ativo neste processo. Corrobora esta assertiva a grande quantidade de lípides e material PAS positivo ao lado dos coxins, os quais podem constituir combustível metabólıco como fonte de energia. Nossas observações indicam a presença dos coxins em toda a extensão da bexiga natatória, o que não concorda com as observaçōes de Kramer (1978), que os observa apenas na porção caudal da câmara posterior. Kramer (1978) afirma também que só a porção anterior da câmara posterior tem função respiratória. As observações histoquimicas por nós efetuadas, parecem sugerir uma atividade respiratória predominante nessa área, porém não é refutada a possibilidacie de ela ocorrer em toda a bexiga, uma vez que os compostos histoquimicamente demonstráveis são vistos em toda sua extensão. Além disso, o plexo capilar subepitelial, embora mais proeminente na câmara posterior, encontra-se também desenvolvido na câmara anterior, sugerindo que esta porção do órgão, tamiém pode atuar na respiração. Kramer (1978) mostra através de cinematografia com raio $\mathrm{X}$, que a 
câmara anterior tem papel importante no processo ventilatório, separando o gás expirado do gás inspirado na mesma respiração.

O método da aldeído-fucsina, de Gomori (1950), que demonstra seletivamente fibras elásticas, foi visto corar uma variedade de mucossubstâncias ácidas (Abu'l Haj \& Rinehart, 1952) e mucinas sulfatadas (Spicer \& Meyer, 1960). No presente trabalho, os grânulos grosseiros revelados pela aldeído-fucsina, indicam a presença de tais substâncias, que aliás, corroborativamente, apresentam 0 mesmo padrão de distribuição dos grânulos grosseiros PAS positivos.

Da comparação histoquímica das duas espécies estudadas, é aparente que, com o desenvolvimento da respiração aérea, vários compostos químicos se fazem presentes no jeju.

As substâncias PAS+ são, provavelmente, glico-proteínas. Entretanto deve ser considerado que os lípides também podem estar apresentando reatividade, pois, embora não tenne diminuído a intensidade da reação após o prétratamento com desoxicolato de sódio, eles devem existir, pois houve intensa coloração pelo negro de Sudan B. Isto sugere que o componente lipídico deve estar fortemente unido a proteínas. Por outro iado, a presença de glicogênio não foi detectada nem ultraestruturalmente, (Cruz-Landim \& Cruz-Höfling, 1979), nem histoquímicamente, pois a positividade ao PAS manteve-se após a ação da amilase salivar. O material mucopolissacarídico, PAS positivo, observado no jeju, teria função de remover impurezas do ar, nos peixes de respiração aérea (Brooks, 1970).

Quanto ao material lipídico, é muito abundante também no jeju. Phleger \& Saunders (1978) já haviam detectado inúmeros fosfolípides em extratos lavados de bexiga natatória de $H$. unitaeniatus. Ao material lipídico também seriam atribuídas funções semelhantes ao do material mucopolissacarídico e/ou função no impedimento da entrada de água nos capilares presentes na bexiga natatória (Phleger \& Saunders, 1978), ou ainda constituir reservas energéticas, que podem ser utilizadas em períodos grandes de jejum, ou em condições prolongadas de respiração aérea (Singh et al.,
1973). A grande concentração dơs lípides na câmara posterior e sob o epitélio que reveste os coxins, per nós observada no jeju, parece estar de acordo com estas sugestões. A sua quase total ausência nơ aruanã está, provavelmente, ligada ao fato de este órgão ter função hidrostática nesse peixe.

Os componentes lipídicos, glicídicos e mais as proteinas, estas evidenciadas pela técnica de Ninhidrina-Schiff, poderiam possiveimente fazer parte do material surfactante do jeju. Esta assertiva é razoável, desde que estes componentes estão presentes em granulações que apresentam o mesmo padrão de forma e distribuição. A presença de colesterol no jeju näo é por nós explicada. Além de fazer parte das fibras elásticas, também é encontrado em porções da lâmina própria e da capa muscular. Phleger et al. (1977) relata a presença de colesterol, fosfolipides e proteínas em bexigas natatórias de alguns peixes de mares profundos, e sugere que este material teria atividade surpélica, mas a função maior seria a de dissolver $\mathrm{O}_{2}$ para manter a flutuação neutra. Contudo, a função de bexigas natatórias ricas em colesterol não é explicada (Phleger \& Holtz, 1973) .

A presença de calciferol, encontrado por nós em pequenas quantidades no epitélio da bexiga natatória, também não é explicada. Já que as moléculas de colesterol e calciferol são muito semelhantes, é possível que sejam produtos de metabolismo.

A basofilia do epitélio, observada quando se efetuou a reação para o tocoferol, pode ser devida à presença desta vitamina. Hadler (comunicação pessoal) diz que este resultado só é válido quando o fixador utilizado na preservação do material contiver bicloreto de mercúrio, o que não ocorreu neste trabalho. Entretanto, se fosse confirmada a presença de tocoferol, este provavelmente, teria papel na antioxidação dos lípides da bexiga natatória, os quais estão sujeitos às altas tensões de $\mathrm{O}_{2}$ que ocorrem nesse órgão. Haugaard (1969) afirma que os danos celulares causados por altas concentrações de $\mathrm{O}_{2}$, podem ser causados pela oxidação ou peroxidação dos lípides e possivel inativação de coenzimas contendo -SH. Por outro lado, Brooks (1970) sugere que 
os citossomas produziriam anti-oxidantes para proteção contra os efeitos tóxicos do $\mathrm{O}_{2}$. Foram encontrados citossomas na bexiga natatória das duas espécies de peixes estudadas no presente trabalho (Cruz-Landim \& CruzHöfling, 1979)

Os grupos redutores encontrados na bexiga natatória não são grupamentos sulfidrila. Isto pode ser devido ao fato de serem aitamente susceptiveis à oxidação, transformando-se em grupos dissulfetos, pela ação do $\mathrm{O}_{2}$ atmosférico na presença de sais férricos. Íons férricos foram observados principalmente, no loca! das granulações grosseiras PAS positivas.

Finalmente, os mastócitos presentes na lâmina própria e adventicia, podem ter relação com os mecanismos de vasoconstrição e per. meabilidade capilar nas diferentes sıtuações fisiológicas.

\section{AgradeCIMENTOS}

Agradecemos ao Dr. W. E. Kerr por ter-nos indicado para participar da expedição, ao $\mathrm{Dr}$. C. Nicol, chefe da fase IV da expedição do R/V Alpha-Helix e à tripulação, por ter-nos proporcionado agradável estadia a bordo. Aos Drs. Naércio A. Menezes e Heraldo A. Britski pela identificação dos peixes e, ao Dr. W. A. Hadier, do Departamento de Morfologia da UNICAMP pela leitura e crítica do manuscrito. A Sra. Alaíde Pedro Franco Correa pelos trabalhos técnicos e à Srta. Vânia Aparecida Baroni pelos trabalhos datilográficos.

\section{SUMMARY}

Morphological and histochemical comparisons were nade between the swim-bladders of Hoplerythrinus unitaenitus (the "jeju"), a facultatively air breathing eritrin:d fish, and Osteoglossum bicirrhosum (the "aruanã"), an osteoglossid fish which is restricted to aquatic respiration. In the "jeju", the swim-bladder has a respiratory function, while in the "aruanã" it is an hydrostatic organ. Both are physostomes, and the swim-bladder is divided into two chambers whose walls are made up of three enveloping membranes or mantles. There are morphological characteristics peculiar to each species, especially in the form of the mantles. In "the "jeju" the mantle forms folds, which increase the surface area. The mantle also has a rich plexus of sub-epithelial capillaries and lateral muscular pads in this species.
The histochemical tests show that the swim-bladder of the "jeju" contains mucopolysaccharides, reducing substances, lipids, cholesterol and the related compounds: calciferol, ferric ions, and proteins. There are also elastic fibers which are present in greater quantity in the anterior portion of the posterior chamber. With the exception of the elastic fibers, these components are usually located in the epithelium, the stripe itself, and near the blood vessels, especially near the muscular pads. In the "arună" the tests for these substances were negative, except for a few which were discretely positive in the epithelium and in the presence of elastic fibers.

It is suggested that the compounds found in the "jeju" have a function in the respiration carried out by the swim-bladder.

\section{BIBLIOGRAFIA}

ABu'L, S.K. \& RiNeHART, J.F.

1952 - Fuchsin aldehyde staining of sulfated mucopolysaccharides. J. Nat. Cancer Inst., $13: 232-233$.

ADAMS, C.W.M.

1956 - A stricted interpretation of ferricferricyanide reaction with particular reference to the demonstration of protein-bound sulphydril and dissulphide groups. J. Histochem. Cytochem., $4: 23-55$

BROOKS, R.E.

1970 - Lung alveolar cell cytosomes: a consideration of their significance. Z. Zellforesch., $106: 484-497$.

Brown, E.S.

1964 - Isolation and assay of dipalmitoyl lecithin in lung extracts. Am. J. Physiol., 207 : $402-406$.

CARTER, G.S.

1957 - Air breathing. In: Physiology of fishes. Vol. I. Metabolism. Ed. by M.E. Brown. Acad. Press, New York, p. 65-79.

Cruz-landim, C. \& Cruz-Höfling, M.A.

1979 - Diferenças ultraestruturais entre bexigas natatórias de peixes teleósteos de respiração aquática e respiração aérea. Acta Amazonica, $9(2): 317-323$.

GOMORI, G.

1950 - Aldehyde-fuchsin: A new stain for elastic tissue. Am. J. Clin. Path., 20 : 665-666.

Graham, J.B.; Kramer, D.L. \& Pineda, E.

1978 - Comparative respiration of an air-breathing and a non-air-breathing characin fish and the evolution of aerial respiration in characines. Physiol. Zool., 50:279-288.

Hadler, W.A.; ZitTI, L.M.; Lucca, O. DE \& Patelli, A.S

1968 - A new technique for histochemical detection of cholesterol and cholesterollike compounds. Acta histochem., 30:70-78. 
Hadler, W.A.; Lucca, O. DE; ZITH, L.M. \& PATELLI, A.S.

1969 - A quantitative study on the most effective conditions to develop the prussian blue reaction for histochemical detection of ferric ion. Rev. Bras. Pesq. Med. Biol., $2: 344-347$

Hadler, W.A. \& SILveirA, S.R.

1977 - Novas técnicas para demonstracăo histoquímica de tocoferol e de vitamina $D$. Ciência e Cultura, 29(7): 584 .

HaUgard, N.

1969 - Cellular mechanism of oxygen toxicity. Physiol, Rev., $48: 311-373$.

HотснкISS, R.D.

1948 - A microchemical reaction resulting in the staining of polysaccharide struture in fixed tissue preparation. Arch. Biochem., 16: 131-141.

Hughes, G.M.

1966 - Evolution between air water. Ciba Foundation Symp. on Develop. of Lung. Ed. by de REUCK and PORTER, Churchill Ltd. London, p. $64-80$

1973 - Ultraestructure of the lung of Neocera. todus and Lepidosiren in relation to the lung of other vertebrates. Folia Morph. (Warsaw) 21:155-161

Hughes, G.M. \& Wetbel, E.R.

1978 - Visualization of layers lining the lung of South American lungfish rLepidosiren paradoxa) and a comparison with the frog and rat. Tissue and Cell, $10: 343-353$.

JOHANSEN, $\mathrm{K}$.

1970 - Air breathing in fishes, In: Fish Physiology. Vol. IV Cap. 9 Ed. W.S. HOAR and D. J. Randall. Acad. Press, New York. p. 361-411.

Johansen, K.; Lenfant, C.; Peterson, J. \& SchmidtNIELSEN, K.

1967 - Dynamics of gas exchange and control of breathing in the electric eel, Electrophorus electricus. Progress Report, R/V AlphaHelix Amazon Expedition 1967. Scripps Institute of Oceanography. Univ. of California, San Diego.

Jones, F.R.H. \& MARshall, N.B.

1953 - The structure and functions of the teleostean swimblader. Biol. Rev., 28 : 16-83.

Junqueira, L.C.; Steen, J.B. \& Tinoco, R.M.

1967 - The respiratory area of girlls of teleosts from Rio Negro and Rio Branco area. Progress Report, R/V Alpha-Helix Amazon Expedition, Scripps Institute of OceanoKRAMER, D.L. graphy, University of California, San Diego.

1978 - Ventilation of the respiratory gas bladder in Hoplerythrinus unitaeniatus (Pisces;
Characoidei, Erythrinidae). Can. J. Zool., 56 : $931-938$.

Lison, L.

1960 - Histochemie et Cytochemie Animales Principles et Methodes Paris, Gauthiers Villars.

LÜLING, K.H.

1964 - Ober die Atmung des Hoplerythrinus unitaeniatus (Pisces, Erythrinidae). Bonn. Zool. Beitr., $15:$ 90-102.

McManus, J.F.A.

1946 - The histochemical demonstration of mucins after periodic acid. Nature, 158: 202.

PAttle, R.E.

1955 - Properties, function and origin of the alveolar lining layer. Nature, 175:1125-1126.

1976 - The lung surfactant in the evolutionary tree. In: Respiration of amphibious vertebrates, Ed. by G.M. Hughes, Acad. Press. New York, p. 233-255.

PATtLe, R.E. \& Hopkinson, D.A.W

1963 - Lung lining in bird, reptile and amphibian. Nature, $200: 894$

Phleger, C.F. \& Holtz, R.B.

1973 - The membranous lining of the swimbladder in deep sea fish - 1. Morphology and chemical composition. Comp. Biochem. Physiol., $45:$ : 867-873.

Phleger, C.F.; Grimes, P.W.; Besely, A. \& Horn, M.H.

1977 - Swimbladder lipids of five deep Atlantic Ocean fish species. Bull. Mar. Scien. In press.

Phleger, C.F. \& SAunders, B.S.

1978 - Swimbladder surfactents of Amazon air breathing fishes, Can. J. Zool., $56: 946-952$.

Singh, B.R.: GUHA, G. \& MUNSHI, J.S.D.

1973 - Fat depot in the air-breathing organs of some teleosts. Z. mikrosk, anat. Forsch. Leipzig. $87: 242-248$.

SPICER, S.S. \& MEYER, D.B.

1960 - Histochemical differentiation of acids mucopolysaccharides by means of cimbined aldehyde fuchsin - alcian blue staining. Am. J. Clin. Path., 33:453-460.

WEIBEZAHN, F.H.

1967 - Estudios sobre la respiracion aerea en Hoplerythrinus unitaeniatus (Spix) (Cypriniformes, Characidae). Bol. Soc. Venez. Scien. Nat., $27: 178-188$.

YASUMA, A. \& ITCHIKAWA, T.

1953 - Ninhydrin-Schiff and Aloxan Schiff staining. J. Lab. Clin. Med., 41: 196-299.

(Aceito para publicação em $5 / 08 / 79$ ) 